\title{
Food availability outweighs ocean acidification effects in juvenile Mytilus edulis: laboratory and field experiments
}

\author{
JÖRN THOMSEN*1, ISABEL CASTIES*1, CHRISTIAN PANSCH ${ }^{*}$, ARNE KÖRTZINGER $†$ and \\ FRANK MELZNER* \\ ${ }^{*}$ Marine Ecology, GEOMAR Helmholtz Centre for Ocean Research, Kiel 24105, Germany, †Chemical Oceanography, GEOMAR \\ Helmholtz Centre for Ocean Research, Kiel, 24105 Germany
}

\begin{abstract}
Ocean acidification is expected to decrease calcification rates of bivalves. Nevertheless, in many coastal areas high $p \mathrm{CO}_{2}$ variability is encountered already today. Kiel Fjord (Western Baltic Sea) is a brackish $\left(12-20 \mathrm{~g} \mathrm{~kg}^{-1}\right)$ and CO enriched habitat, but the blue mussel Mytilus edulis dominates the benthic community. In a coupled field and laboratory study we examined the annual $p \mathrm{CO}_{2}$ variability in this habitat and the combined effects of elevated $p \mathrm{CO}_{2}$ and food availability on juvenile $M$. edulis growth and calcification. In the laboratory experiment, mussel growth and calcification were found to chiefly depend on food supply, with only minor impacts of $p \mathrm{CO}_{2}$ up to $3350 \mu$ atm. Kiel Fjord was characterized by strong seasonal $p \mathrm{CO}_{2}$ variability. During summer, maximal $p \mathrm{CO}_{2}$ values of $2500 \mu$ atm were observed at the surface and $>3000 \mu \mathrm{atm}$ at the bottom. However, the field growth experiment revealed seven times higher growth and calcification rates of $M$. edulis at a high $p \mathrm{CO}_{2}$ inner fjord field station (mean $p \mathrm{CO}_{2} \mathrm{ca}$. $1000 \mu$ atm) in comparison to a low $p \mathrm{CO}_{2}$ outer fjord station (ca. $600 \mu \mathrm{atm}$ ). In addition, mussels were able to out-compete the barnacle Amphibalanus improvisus at the high $p \mathrm{CO}_{2}$ site. High mussel productivity at the inner fjord site was enabled by higher particulate organic carbon concentrations. Kiel Fjord is highly impacted by eutrophication, which causes bottom water hypoxia and consequently high seawater $p \mathrm{CO}_{2}$. At the same time, elevated nutrient concentrations increase the energy availability for filter feeding organisms such as mussels. Thus, M. edulis can dominate over a seemingly more acidification resistant species such as $A$. improvisus. We conclude that benthic stages of $M$. edulis tolerate high ambient $p \mathrm{CO}_{2}$ when food supply is abundant and that important habitat characteristics such as species interactions and energy availability need to be considered to predict species vulnerability to ocean acidification.
\end{abstract}

Keywords: adaptation, Amphibalanus improvisus, calcification, $\mathrm{CO}_{2}$ enriched ecosystem, community response, energy availability, eutrophication, field study, Mytilus edulis, ocean acidification

Received 16 July 2012 and accepted 14 November 2012

\section{Introduction}

Increasing atmospheric $\mathrm{CO}_{2}$ concentrations and subsequent uptake by the oceans lead to increases in seawater $\mathrm{CO}_{2}$ partial pressures $\left(p \mathrm{CO}_{2}\right)$ and decreases in $\mathrm{pH}$ and $\left[\mathrm{CO}_{3}{ }^{2-}\right]$ (Cao \& Caldeira, 2008). In contrast to the open ocean, where seawater $p \mathrm{CO}_{2}$ is close to atmospheric values, $p \mathrm{CO}_{2}$ in coastal habitats is much more variable (Feely et al., 2010; Cai et al., 2011; Melzner et al. 1 2012, Hofmann et al., 2011). Shallow temperate estuaries such as the Western Baltic Sea, with a strong seasonal vertical stratification due to salinity and temperature gradients are characterized by higher and more fluctuating seawater $p \mathrm{CO}_{2}$ (Thomsen et al., 2010; Melzner et al. 2012, Haynert et al., 2012). In these areas, community respiration leads to decreases in $\mathrm{pO}_{2}$ and increases in $p \mathrm{CO}_{2}$ below the thermocline. Although this

Correspondence: Jörn Thomsen, tel. +49 431 6004466, fax +49 431 6001671, e-mail: jthomsen@geomar.de

${ }^{1}$ These authors contributed equally to this work. is a common natural process in the Baltic Sea, it is strongly amplified by high primary production caused by eutrophication from sewage discharge and agriculture (HELCOM, 2009). Upwelling of water masses with high dissolved inorganic carbon content to the surface drastically elevates the $p \mathrm{CO}_{2}$ in the surface layer of Kiel Fjord during summer and autumn. Due to low alkalinity, calcium carbonate saturation states $(\Omega)$ are permanently low and undersaturation frequently occurs (Thomsen et al., 2010; Haynert et al., 2011). Future ocean acidification might lead to very high summer and autumn seawater $p \mathrm{CO}_{2}$ in such habitats, with regular occurrence of $p \mathrm{CO}_{2}$ levels $>2000 \mu \mathrm{atm}$ likely by the year 2100 (Melzner et al. 2012).

Ocean acidification is expected to lower biomineralization rates of calcifiers and to cause net shell dissolution at high $p \mathrm{CO}_{2}$ levels in species with insufficient external shell protection (Haynert et al., 2011; Lischka et al., 2011). Nevertheless, several recent studies also revealed unchanged or even increased calcification at high $p \mathrm{CO}_{2}$ in a range of invertebrates (Ries et al., 2009; 2

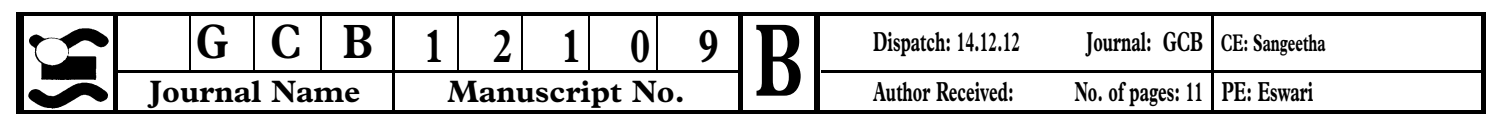


Thomsen et al., 2010; Pansch et al., 2012b) indicating a considerable potential for acclimation or adaptation to high $p \mathrm{CO}_{2}$. As most of the present laboratory studies only covered a relatively short fraction of the total lifespan of metazoans, their predictive power is limited. Therefore, $\mathrm{CO}_{2}$ enriched habitats provide the possibility to investigate long-term acclimation or even adaptation to elevated $p \mathrm{CO}_{2}$. A gradual decline of the number of calcifying species has been observed along a natural $p \mathrm{CO}_{2}$ gradient in the Mediterranean (Hall-Spencer et al., 2008), similar observations were made along a tropical $p \mathrm{CO}_{2}$ gradient (Fabricius et al., 2011). A field study on the US west coast reported a decline in mussel abundance and size with lowered $\mathrm{pH}$ during an 8-year period (Wootton et al., 2008). In contrast, benthic metazoan communities in Kiel Fjord are dominated by calcifying invertebrates such as the mussel Mytilus edulis and the barnacle Amphibalanus improvisus (Thomsen et al., 2010; Pansch et al., 2012a,b). Considering the low $\Omega$ and high $p \mathrm{CO}_{2}$ in this habitat, it is not clear how calcifying species can dominate.

Calcification is a complex, biologically controlled process. In adult mussels, it is not a simple, direct function of seawater $\left[\mathrm{CO}_{3}{ }^{2-}\right]$. Inorganic carbon for biomineralization originates from $\mathrm{HCO}_{3}{ }^{-}$that is transported into or generated within cells. Shell $\mathrm{CaCO}_{3}$ and a diverse set of shell organic matrix molecules are most likely produced intracellularly and are exported to sites of incipient biomineralization (Jacob et al., 2008; Weiner \& Addadi, 2011). Furthermore, a number of invertebrates protect their external shells from the surrounding water with chemically robust organic covers such as the periostracum in the case of bivalves (Waite et al. 3 1979). Therefore, shell production is not necessarily exclusively driven by seawater $\left[\mathrm{CO}_{3}{ }^{2-}\right]$, but is an energetically costly process, primarily due to the production of the organic shell components (Palmer, 1992). As a consequence, a relatively large fraction of the energy budget is allocated to shell production. Reduced calcification in adult $M$. edulis may thus simply result from an energetic trade-off. Recent measurements of increased metabolic rates under elevated $p \mathrm{CO}_{2}$ indicate elevated costs for homeostatic processes. Increased maintenance cost could depress scope for growth and biomineralization (Thomsen \& Melzner, 2010). $\mathrm{A} \mathrm{CO}_{2}$ induced shift of the cellular energy budgets towards ion regulatory processes and a reduction in scope for growth have recently demonstrated in marine animals (Deigweiher et al., 2009; Stumpp et al., 2011).

Here we present findings of a high dependence of mussel growth and calcification on food supply in laboratory and field experiments. High food supply enables a high $\mathrm{CO}_{2}$ stress resilience of mussel growth and calcification. This enables M. edulis to dominate the high $p \mathrm{CO}_{2}$ habitat in Kiel Fjord and out-compete seemingly more $\mathrm{CO}_{2}$ tolerant organisms. Our study emphasizes the need to carefully consider the main biotic and abiotic habitat characteristics to predict species responses to ocean acidification.

\section{Material and methods}

\section{Laboratory study}

For the laboratory study, settled post larvae of the genus Mytilus were used. The Mytilus population in the Baltic Seal is a hybrid population of $M$. trossulus and M. edulis, with progressively more $M$. trossulus alleles towards the east (Stuckas et al., 2009). As the available evidence suggests that $>80 \%$ of alleles in Kiel Fjord animals originate from M. edulis (Stuckas et al., 2009; Breusing, Stuckas, Reusch, Melzner unpublished observation). We will for simplicity's sake refer to Kiel mussels as M. edulis. To capture freshly settled mussels, $5 \times 5 \mathrm{~cm}$ PVC settlement panels, which were roughed on one side using sandpaper (grain 60), were suspended in the fjord (IF station) at $1 \mathrm{~m}$ water depth. After 10 days, panels were removed from $\mathbf{4}$ the fjord and all settled organisms other than 100 settled M. edulis larvae were removed with the help of forceps after viewing under a stereo microscope. Subsequently, single plates were transferred into $500 \mathrm{~mL}$ aquaria in a $17{ }^{\circ} \mathrm{C}$ constant temperature room. For the 7-week laboratory experiment, four $p \mathrm{CO}_{2}$ treatments, 470, 1020, 2110, and $3350 \mu \mathrm{atm}$, and three feeding regimes (low, intermediate and high) were realized. In total, 12 different treatments with seven replicates each were used. The $p \mathrm{CO}_{2}$ treatment levels used correspond to present day and projected future levels in this area (Thomsen et al., 2010). Aquaria were filled with $0.2 \mu \mathrm{m}$ filtered and UV-radiated seawater from the fjord and aerated with compressed air with one of four $p \mathrm{CO}_{2}$ levels (see Thomsen et al., 2010 for details). Water exchange of $400 \mathrm{~mL}$ (80\%) was performed daily using $\mathrm{CO}_{2}$ and temperature pre-equilibrated water. Measurements of salinity, temperature, and $\mathrm{pH}_{\mathrm{NBS}}$ were performed daily in 24 of the 84 aquaria. For carbonate chemistry, $250 \mathrm{~mL}$ water samples were taken and $\mathrm{pH}$ on the total scale $\left(\mathrm{pH}_{\mathrm{T}}\right)$ and $\mathrm{C}_{\mathrm{T}}$ were determined using a Metrohm 6.0262.100 electrode and 626 Metrohm pH meter and an AIRI$\mathrm{CA} C_{\mathrm{T}}$ analyser (Marianda, Kiel, Germany). Water samples were analysed within $2 \mathrm{~h}$ of sampling. $\mathrm{pH}_{\mathrm{T}}$ was determined using Tris $/ \mathrm{HCl}$ and $\mathrm{AMP} / \mathrm{HCl}$ seawater buffers mixed for a salinity of 15 (Dickson et al., 2007) in a $21{ }^{\circ} \mathrm{C}$ water bath. Accuracy of $A_{\mathrm{T}}$ and $C_{\mathrm{T}}$ measurements was ensured by using certified reference material (Dickson et al., 2003). The carbonate system speciation was calculated using the CO2SYS program (Lewis \& Wallace, 1998). For calculations, the $\mathrm{KHSO}_{4}$ dissociation (Dickson et al. 2005) and the carbonate system dissocia- $\mathbf{5}$ tion constants $K_{1}$ and $K_{2}$ (Roy et al., 1993) were used.

Three feeding treatments were established by addition of exact cell numbers of Rhodomonas sp. algae to the experimental aquaria. At weekly intervals, algae cell concentrations were increased and the number of mussels was reduced to compensate for mussel growth (Supplementary Table S1). Initial algal supply in the different food treatments was 5000, 2500, and 
500 cells $\mathrm{mL}^{-1}$, respectively, which was increased up to 40 000, 20 000, and 4000 cells $\mathrm{mL}^{-1}$ during the last week. The ratio of $10: 5: 1$ between the feedings levels was maintained during the entire experiment. The algae cells were cultured in $0.2 \mu \mathrm{m}$ filtered seawater with Provasoli's enriched seawater (PES) medium and elevated phosphate $\left(0.036 \mathrm{mmol} \mathrm{L}^{-1}\right)$ and nitrate $\left(0.55 \mathrm{mmol} \mathrm{L}^{-1}\right)$ concentrations as previously described (Thomsen et al., 2010). Once a day, Rhodomonas culture densities were measured using a particle counter (Z2 Coulter Particle count and size analyser, Beckman Coulter, Krefeld, Germany) to calculate the culture volume that had to be added to reach the desired cell densities in the aquaria. Weekly, particulate organic carbon (POC) content of the supplied algae and of algae concentrations following 24-h incubation was analysed. For POC determinations, $500 \mathrm{~mL}$ water samples were obtained with a water sampler from $1 \mathrm{~m}$ depth. Subsequently, samples were filtered on combusted GF/F filters using a vacuum pump and stored at $-20^{\circ} \mathrm{C}$. Before analysis, filters were treated with fuming hydrochloric acid, dried $\left(60{ }^{\circ} \mathrm{C}, 6 \mathrm{~h}\right)$, and wrapped in tin boats. POC determinations were performed using gas chromatography in an elemental analyser Euro Vector 3000 (EuroVector, Milan, Italy). Differences between supplied and remaining POC were used to calculate POC uptake by the mussels. Correlation of measured Rhodomonas cell abundance and POC revealed a carbon content of $45 \mathrm{pg} \mathrm{C}$ cell ${ }^{-1}$.

For determination of initial size (shell length, $\mathrm{CaCO}_{3}$, and total organic content) and weekly growth rates, five to six individuals were sampled at each sampling day from each aquarium and stored in seawater with $4 \%$ paraformaldehyde (PFA). Shell length was measured using a stereo microscope equipped with a MicroPublisher 3.3 RTV camera and the image analysis software Image Pro Plus 5.0.1. Final $\mathrm{CaCO}_{3}$ and total organic content was determined as described above by weighing single specimens using a precision balance (accuracy $\pm 1 \mu \mathrm{g}$, Sartorius, Göttingen, Germany) after drying at $60{ }^{\circ} \mathrm{C}$ and ashing at $500{ }^{\circ} \mathrm{C}$ for $20 \mathrm{~h}$. In addition, shell free drymass (SFDM) was dissected from carefully opened, frozen specimens and dried at $60{ }^{\circ} \mathrm{C}$. Comparison of SFDM and total organic content (TOC $=$ SFDM + organic shell components, OSC) was performed using a regression of both parameters against shell length.

Energy contents of supplied Rhodomonas and seawater POC were estimated using the conversion factor of $46 \mathrm{~J} \mathrm{mg}^{-1}$ POC (Salonen et al., 1976). Mussel SFDM and OSC (periostracum + organic shell matrix) was converted to caloric equivalents using the conversion factor $23 \mathrm{~J} \mathrm{mg}^{-1}$ (Brey et al., 1988). Similarly, the inorganic shell component (ISC) was converted into energy equivalents using a factor of $2 \mathrm{~J} \mathrm{mg}^{-1} \mathrm{CaCO}_{3}$ (Palmer, 1992).

\section{Field studies}

Carbonate chemistry in Kiel Fjord. The carbonate chemistry of Kiel Fjord was monitored on weekly (station 1) and biweekly (stations 2-4) cruises using RV Polarfuchs between April 2009 and March 2010. Two samples (500 mL) were taken at each station from both surface (ca. $1 \mathrm{~m}$ depth) and bottom water ( $1 \mathrm{~m}$ above sea floor, i.e. 11-20 m). Seawater samples were poisoned with saturated mercuric chloride solution and stored at room temperature until analysis according to SOP1 (Dickson et al., 2007). Samples were analysed for $C_{\mathrm{T}}$ and $A_{\mathrm{T}}$ by coulometric and potentiometric titration using SOMMA and VINDTA auto analysers respectively (Dickson et al., 2007). In addition, water samples for nutrient determination $\left(\mathrm{PO}_{4}{ }^{3-}\right.$, $\mathrm{H}_{4} \mathrm{SiO}_{4}$ ) were collected in $10 \mathrm{~mL}$ Falcon tubes and stored at $-20{ }^{\circ} \mathrm{C}$. Analyses were carried out spectrophotometrically using a U-2000 spectrophotometer (Hitachi-Europe, Krefeld, Germany, Hansen and Koroleff 1999). Weekly pH measure- 6 ments (NBS scale) were conducted at an inner Kiel Fjord (station IF, $\left.54^{\circ} 19.8^{\prime} \mathrm{N} ; 10^{\circ} 9.0^{\prime} \mathrm{E}\right)$ and bi-weekly at an outer Kiel Fjord station (station $\mathrm{OF}, 54^{\circ} 25^{\prime} \mathrm{N}, 10^{\circ} 10^{\prime} \mathrm{O}$ ) during the field study using a WTW 340i pH meter and a WTW Sentix 81-electrode. Salinity and temperature were measured at $10 \mathrm{~cm}$ depth using a WTW cond 315i salinometer and a TETRACON 325 probe.

M. edulis growth experiment. For the field study, settlement panels were treated in the same way as stated above for the laboratory study. Panels were transferred to the experimental sites and suspended at $1 \mathrm{~m}$ depths. Both field sites are characterized by similar salinity, temperature, light exposure, and are sheltered from wave action. The number of replicates was six. However, despite the shelter two panels were lost at station OF during storms. Water chemistry $\left(\mathrm{pH}_{\mathrm{T}}, \mathrm{C}_{\mathrm{T}}\right)$ and POC concentrations were monitored bi-weekly at both stations and analysed as described above. POC concentrations were monitored as an indicator for habitat energy supply. The experiment lasted from July 23th to November 19th 2010 (18 weeks). Panels were removed and frozen. Subsequently, pictures were taken to calculate the percentage of coverage for M. edulis and $A$. improvisus on both sides of each panel using Image version 1.45. Fouling organisms were determined to the lowest possible taxonomic level. TOC and ISC of the two species comprising $>99 \%$ of the biomass on the panels (mussels and the barnacles) were determined after drying at $60^{\circ} \mathrm{C}$ overnight and ashing at $500{ }^{\circ} \mathrm{C}$ for $20 \mathrm{~h}$ respectively. In addition, settled post larvae of $M$. edulis were collected at each station every second week starting on August 11th for determination of a shell length growth relationship. Final somatic drymass and shell length and mass were determined from specimens collected on November 19th.

Haemolymph acid-base status. The extracellular acid-base status was determined for M. edulis sampled from the field and laboratory experiments. A haemolymph sample (0.4$0.8 \mathrm{~mL}$ ) was anaerobically drawn from the posterior adductor muscle using gas tight Hamilton syringes and transferred into a $1.5 \mathrm{~mL}$ Eppendorf tube. $\mathrm{pH}_{\mathrm{NBS}}$ was measured using a WTW microelectrode; the measurement became stable after $30 \mathrm{~s} . C_{\mathrm{T}}$ was measured using a Corning $965 \mathrm{CO}_{2}$ analyser (Olympic Analytical, Malvern, UK), which was calibrated with $\mathrm{NaHCO}_{3}$ standards. Acid-base parameters $p \mathrm{CO}_{2},\left[\mathrm{HCO}_{3}{ }^{-}\right]$and $\left[\mathrm{CO}_{3}{ }^{2-}\right]$ were calculated according to the Henderson-HasselbalchEquation as described previously (Thomsen et al., 2010). The systematic error of $\mathrm{pH}$ determination due to gas exchange was 
quantified by monitoring $\mathrm{pH}$ changes during $3.5 \mathrm{~min}$ after stabilization of the initial value. The $\mathrm{pH}$ changed by less than 0.01 units during this period $(n=11$, Supplementary Fig. S5d). Haemolymph acid-base status was monitored for specimens (shell length about $5 \mathrm{~cm}$ ) sampled directly at station IF in 2009 (see supplementary Table S7). Animals were transported in ambient water into the lab. To quantify the effect of handling and transportation on acid-bases status, comparisons were made between haemolymph withdrawn immediately from animals after removal from the fjord $(<15 \mathrm{~s}, n=5)$ and from specimens stored for 5-10 $\mathrm{min}$ in ambient water $(n=6)$. No significant differences were observed between both groups for any acid-base parameter (Supplementary Fig. S5a-c, $t$-test, $P>0.05)$. Furthermore, the effect of flow-through and closed experimental setups on extracellular acid-base status was tested. Specimens were kept at $\mathrm{pCO}_{2}$ levels of 390 and $4000 \mu \mathrm{atm}$ in either closed (no water exchange) or open, i.e. flow-through (100 mL min ${ }^{-1}$ water exchange), setups for 1 week. Subsequently, extracellular acid-base status and carbonate chemistry of the water was determined as described above. Accumulation of $\mathrm{HCO}_{3}{ }^{-}$above the non-bicarbonate buffer line was only observed when animals were kept in laboratory experiments in a closed system without water exchange (Supplementary Figure S5e). In this treatment, shell dissolution due to $\Omega_{\text {aragonite }}<1$ increased $\mathrm{HCO}_{3}{ }^{-}$concentrations of the water and simultaneously increased haemolymph $\mathrm{HCO}_{3}{ }^{-}$concentrations (Supplementary Figure S5E, ANOvA, $\left.F_{(3,16)}=11.4, P<0.01\right)$. In contrast, the flow-through experimental design prevented $\mathrm{HCO}_{3}{ }^{-}$accumulation in the water and also in the haemolymph (Supplementary Table S8).

\section{Statistics}

Regression analyses were performed using Sigma Plot 10, all other statistics were performed with Statistica 8. Data were analysed for normality using Shapiro-Wilks test. For the laboratory results repeated measures ANOVA and two-way ANOVA were applied. Multiple linear regression models for growth were compared using Akaike Information criterion (AIC). For data analyses of the field study, paired t-tests and MannWhitney $U$-tests were used.

\section{Results}

\section{Laboratory experiment}

The carbonate system speciation in the experimental aquaria is given in Supplementary Table S2. Seawater was undersaturated with respect to aragonite in all elevated $p \mathrm{CO}_{2}$ treatments. Survival rates were not affected by any treatment. At the same time, weekly measurements documented an exponential increment in mussel shell length during the experiment (Fig. 1a-c). Feeding regime and $p \mathrm{CO}_{2}$ had significant effects on shell length, inorganic shell component (ISC), and total organic component (TOC) growth (Fig. 1d, repeated measures ANOVA: factor food supply: $F_{(14,132)}=17.86, P<0.01$, factor $p \mathrm{CO}_{2}: F_{(21,190.1)}=1.99, P<0.01$, interaction: $F_{(42,313)}$ $=0.99, P>0.5)$. The observed growth was described best using a two factorial linear model (see Fig. 1 caption). However, AIC analysis revealed that single factor models based on food supply, explained most of the variability encountered in the experiment (Supplementary Table S3).

Inorganic shell component (ISC) growth was significantly affected by food level and $p \mathrm{CO}_{2}$ (Fig. 1d, Twoway ANOVA: factor food supply: $F_{(2,72)}=40.6, P<0.01$, factor $p \mathrm{CO}_{2}: \quad F_{(3,72)}=3.27, \quad P<0.05, \quad$ interaction: $\left.F_{(6,72)}=1.07, P>0.5\right)$, whereas total organic component (TOC) growth was significantly influenced by food supply, but not by $p \mathrm{CO}_{2}$ (Fig. 1d, Two-way ANOva: factor food supply: $F_{(2,72)}=51.84, P<0.01$, factor $p \mathrm{CO}_{2}$ : $F_{(3,72)}=1.19, \quad P=0.32, \quad$ interaction: $\quad F_{(6,72)}=1.02$, $P>0.5)$.

Settled mussels consisted of about $20 \%$ organic and $80 \%$ inorganic $\left(\mathrm{CaCO}_{3}\right)$ material. Approximately $50 \%$ of the produced organic mass consisted of structural organic shell material (OSC), i.e. matrix proteins and carbohydrates as well as periostracum. The remaining organic mass was somatic tissue (shell free drymass, SFDM, Supplementary Fig. S1). Thus, shell mass (OSC and ISC) contributed about $90 \%$ to the final dry mass of the experimental M. edulis. Owing to the lower energy demands for ISC formation, relatively more energy was invested into organic mass growth (Supplementary Fig. S2). We estimate that about $60 \%$ of the total energy necessary for body growth was invested into synthesis of organic and inorganic shell components (Supplementary Table S4). Whereas the shell mineralogy of freshly settled M. edulis is similar to that of older mussels, the organic shell component is much higher in younger mussels ( $>10 \%$, Supplementary Table S4) than in fully grown mussels (1-6\%, Supplementary Table S5). The proportions of OSC vs. ISC did not significantly change with $p \mathrm{CO}_{2}$ (Supplementary Table S4). Our study demonstrates the ability of freshly settled M. edulis to calcify under highly elevated $p \mathrm{CO}_{2}$ when nutritional supply is sufficient.

\section{Field studies}

Carbonate chemistry in Kiel Fjord. In the field, long-term monitoring confirmed that inner Kiel Fjord (IF) is characterized by elevated mean $p \mathrm{CO}_{2}$ values and a large seasonal $p \mathrm{CO}_{2}$ variability. Occasional upwelling of hypoxic bottom water in late summer and autumn leads to increased $p \mathrm{CO}_{2}$ and lowered $\mathrm{pH}$ (Fig. 2, Supplementary Table S6). Surface $\mathrm{pH}_{\mathrm{NBS}}$ is highly variable, with high values of about 8.0-8.1 during spring and early summer and low values down to about 7.3 in late summer and autumn (Fig. 2b). In addition, $\mathrm{pH}_{\mathrm{NBS}}$ can vary 

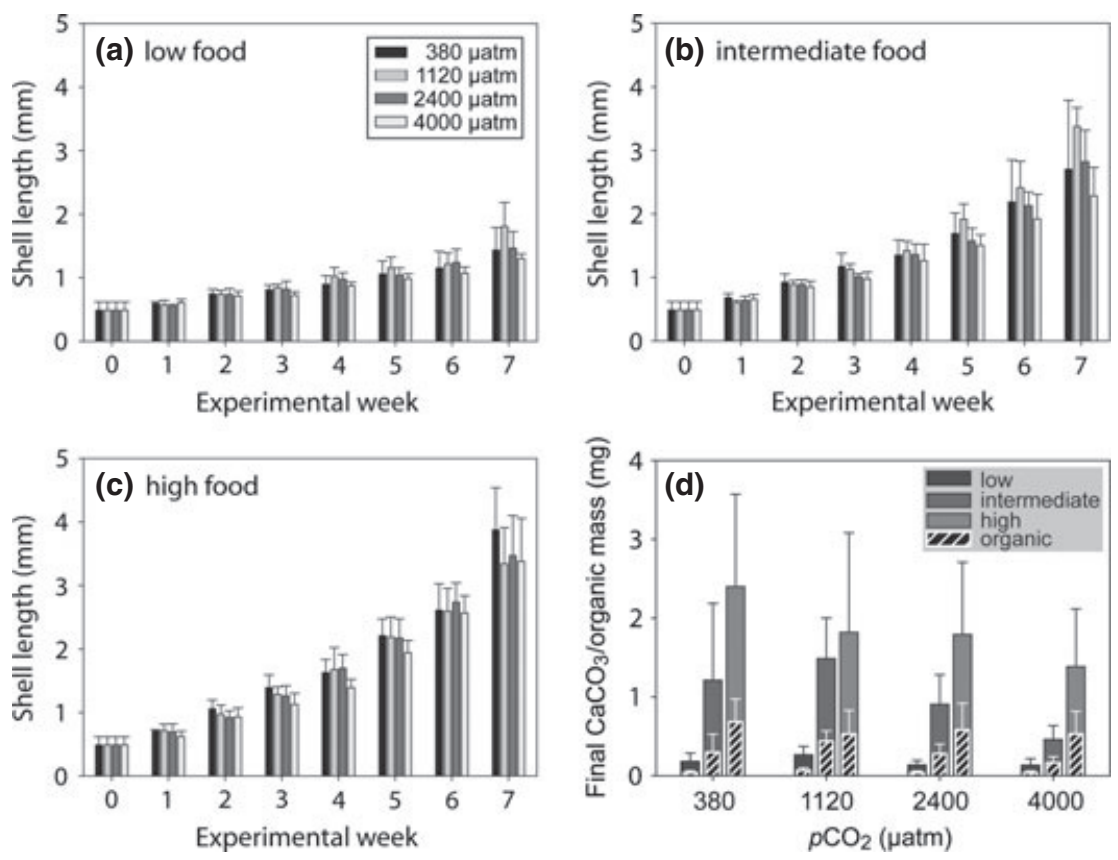

Fig. 1 Mytilus edulis shell and somatic growth during the experiment. Weekly measured shell length of mussels from the four $p \mathrm{CO}_{2}$ and three feeding treatments $(\mathrm{a}-\mathrm{c})$. Shell length growth (SLG) could best be described with the following two factorial linear regression: SLG $\left(\mu \mathrm{m} 7\right.$ weeks $\left.^{-1}\right)=1312.2( \pm 150.6)-0.148( \pm 0.06) p \mathrm{CO}_{2}(\mu \mathrm{atm})+46.83( \pm 3.81)$ energy supply $(\mathrm{J}), R^{2}=0.66, F_{(2,81)}=78.4$, $P<0.01$, means $\pm \mathrm{SE}$ (a-c). Final shell $\mathrm{CaCO}_{3}$ growth (filled bars) and total organic growth (SFDM $+\mathrm{OSC}$, striped bars, CaCO ${ }_{3}:$ Twoway ANOVA: factor energy: $F_{(2,72)}=40.6, P<0.01$, factor $p \mathrm{CO}_{2}: F_{(3,72)}=3.27, P<0.05$, interaction: $F_{(6,72)}=1.07, P<0.5$, total organic: two-way ANOvA: factor energy: $F_{(2,72)}=51.84, P<0.01$, factor $p \mathrm{CO}_{2}: F_{(3,72)}=1.19, P>0.05$, interaction: $F_{(6,72)}=1.02, P<0.5(\mathrm{~d}) . n=7$ for all treatments. Bars represent means \pm SD.

by more than 0.5 units within a few days. The same was observed for $p \mathrm{CO}_{2}$. Highest measured surface $p \mathrm{CO}_{2}$ values were around $2500 \mu \mathrm{atm}$ in August 2010 (Fig. 2a). Mean annual surface $p \mathrm{CO}_{2}$ decreased from the inner to outer parts of the fjord (from 706 at station 1 to $447 \mu \mathrm{atm}$ at Station 4). Highest $p \mathrm{CO}_{2}$ values were observed between April and November in the inner fjord and in the bottom waters at all stations. Annual mean $p \mathrm{CO}_{2}$ is around $1000 \mu \mathrm{atm}$ at $>15 \mathrm{~m}$ depths in Kiel Fjord and adjacent areas, maximum values of $3400 \mu \mathrm{atm}$ were recorded in August 2010 (Fig. 2a). Kiel Fjord calcium carbonate saturation state was found to be low during the entire seasonal cycle. Inner fjord surface $\Omega_{\text {aragonite }}$ was lower than 1 in 35 of 55 weeks $(64 \%$ of all investigated weeks). At water depths $>15 \mathrm{~m}$, $\Omega_{\text {aragonite }}$ was $<1$ almost during the entire investigated period ( $98 \%$ of all investigated weeks).

M. edulis growth experiment. The carbonate system speciation was similar at stations IF and OF during the field M. edulis growth study. Mean $p \mathrm{CO}_{2}$ was variable at both stations, yet significantly higher at station IF (969 $\mu \mathrm{atm}$, Table 1) in comparison to station OF $(599 \mu \mathrm{atm}$, Table 1, Fig. $3+4 \mathrm{f}$, paired $t$-test $t=2.46$, $P<0.05, N=7$ ). Therefore, mean $\mathrm{pH}, \Omega_{\text {calcite, }}$ and
$\Omega_{\text {aragonite }}$ were also lower at IF (Fig. $4 \mathrm{~d}-\mathrm{-e}$, Table 1). At station IF, POC concentrations were about twice as high as observed at station OF (Fig. 4c, Table 1). During the study period, POC concentrations decreased with time at both stations reflecting the seasonal succession of plankton communities typical for this area. IF shell growth was about $1.1 \mathrm{~mm}^{\text {week }}{ }^{-1}$ whereas $\mathrm{OF}$ mussels grew by only $0.5 \mathrm{~mm}$ week $^{-1}$ (Supplementary Fig. S3). Final shell lengths of $M$. edulis grown on the settlement panels were 18.3 and $9.4 \mathrm{~mm}$ at stations IF and OF ( $U=166, Z=4.65, P<0.01)$ respectively. Shells from both stations were characterized by a similar lengthmass relationship (Fig. $4 \mathrm{~b}$ ). Differences were more pronounced for mean shell mass $(226 \mathrm{mg}$ vs. $33.0 \mathrm{mg}$, $U=166, Z=4.42, P<0.01)$ and SFDM $(51.1 \mathrm{mg}$ vs. $5.8 \mathrm{mg}, U=167, Z=4.33, P<0.01$ ).

Settlement panels were almost completely dominated by M. edulis at both stations and only the barnacle A. improvisus was able to exclusively cover smaller parts of the panels at station OF (Fig. 3, Supplementary Fig. S4). Few other metazoan taxa were detected on single panels in negligible abundances (Table S4). At station $\mathrm{IF}$, barnacles were fully overgrown by $M$. edulis and a large number was found to be dead underneath the mussels (Table 2). During the experiment, secondary $\mathbf{7}$ 

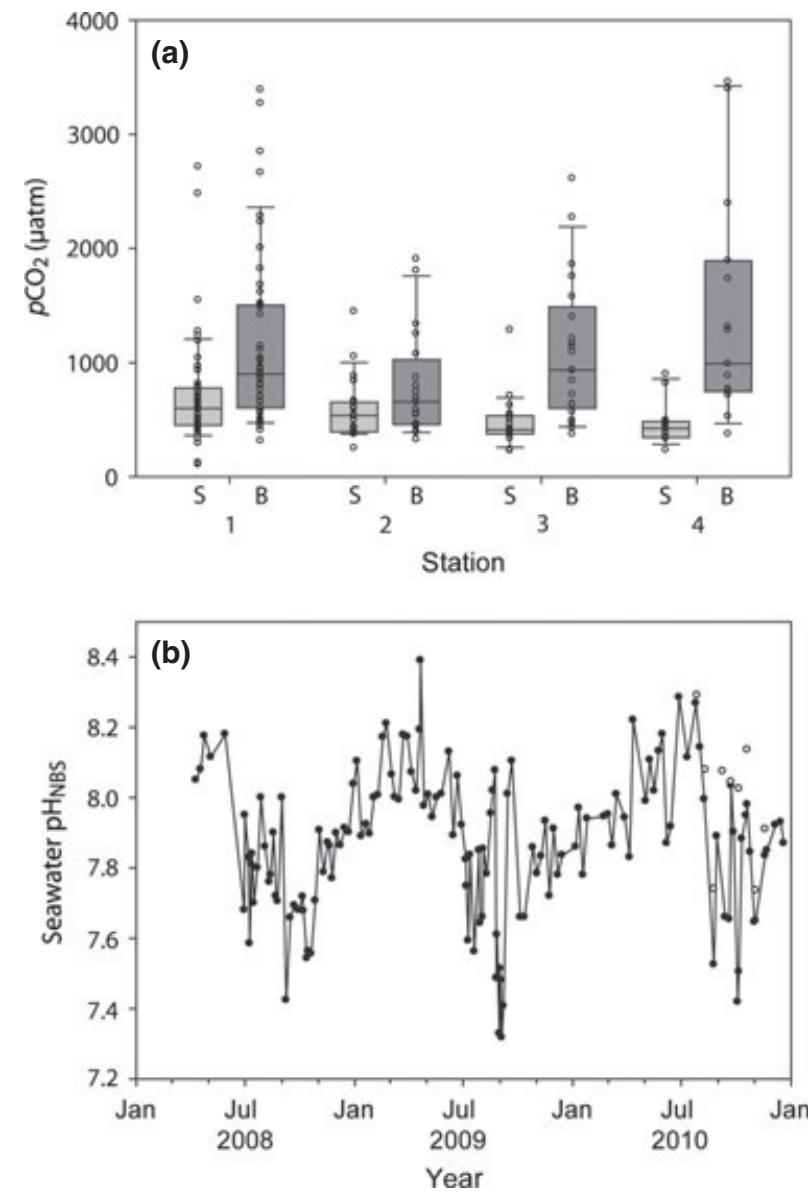

Fig. 2 Box-whisker-plot of Kiel Fjord $p \mathrm{CO}_{2}$ in 2009/2010 measured at stations 1-4 in surface (light grey, $S$ ) and bottom (dark grey, B) water samples. Circles depict individual measurements (a); Time course of surface $\mathrm{pH}_{\mathrm{NBS}}$ in inner Kiel Fjord (station IF, closed circles) between 2008 and 2010 (data from 2008-2009 adopted from Thomsen et al., 2010) and at station OF during the field experiment (open circles), (b).

settlement of mussel larvae took place and led to final numbers of about 600-700 mussels per settlement panel (area of $2 \times 25 \mathrm{~cm}^{2}$ ). Production of calcium carbonate by mussels (101.2 g per panel) at IF exceeded that of OF (13.8 g per panel) panels by a factor of 7 . In contrast, barnacle survival ( $24 \%$ vs. $63 \%$ ) and calcification $(8.0 \mathrm{~g}$ vs. $14.2 \mathrm{~g}$ per panel) rates were reduced at station IF compared to OF due to mussel dominance (Table 2, Fig. 4a).

Haemolymph acid-base status. Haemolymph acid-base status was monitored in adult M. edulis at locations close to station IF with respect to seawater carbonate chemistry. Our sampling programme revealed that mussel extracellular $\mathrm{pH}$ can be described as a linear function of seawater pH (Fig. 5). In August and September, haemolymph $\mathrm{pH}$ was significantly reduced to
7.36 and haemolymph $p \mathrm{CO}_{2}$ increased to $3090 \mu \mathrm{atm}$ as a consequence of low seawater ph and high $p \mathrm{CO}_{2}$ during upwelling events (Supplementary Table S7). Mean haemolymph $\left[\mathrm{CO}_{3}{ }^{2-}\right]$ was $30.4 \mu \mathrm{mol} \mathrm{L}{ }^{-1}$ and ranged between 30 and $66 \%$ of the ambient seawater $\left[\mathrm{CO}_{3}{ }^{2-}\right]$ concentration.

\section{Discussion}

Our laboratory experiment results reveal a high tolerance of the earliest benthic stage of $M$. edulis towards elevated $p \mathrm{CO}_{2}$. For the first time, we could demonstrate that freshly settled $M$. edulis survive high seawater $p \mathrm{CO}_{2}$ and calcify at high rates when nutritional supply is sufficient. Compared to nutritional supply, $p \mathrm{CO}_{2}$ has only a minor impact on growth and calcification of settled M. edulis in both laboratory and field experiments.

A significant reduction of calcification was only observed at very high $p \mathrm{CO}_{2}$ of $3350 \mu \mathrm{atm}$ in our laboratory experiment. Our results contrast with studies on freshly settled stages of other bivalve species, which exhibited lower growth and survival, even at moderately elevated $p \mathrm{CO}_{2}$ below $1500 \mu \mathrm{atm}$ (Talmage \& Gobler, 2010).

Our 1-year monitoring of the carbonate system variability confirmed the high annual variability of $p \mathrm{CO}_{2}$ and $\mathrm{pH}$ in the inner parts of Kiel Fjord (Thomsen et al., 2010). Peak $p \mathrm{CO}_{2}$ observed during summer months in inner Kiel Fjord can reach $>2000 \mu \mathrm{atm}-p \mathrm{CO}_{2}$ levels that have been shown to cause abnormal development of M. galloprovincialis (Kurihara et al., 2008). High and variable seawater $p \mathrm{CO}_{2}$ is related to occasional upwelling of hypoxic-hypercapnic bottom water driven by southerly winds. Whereas oxygen rapidly equilibrates with the atmosphere, elevated $p \mathrm{CO}_{2}$ persists in the surface waters for longer time periods. Similarly high degrees of variability in $p \mathrm{CO}_{2}$ were documented along volcanic $\mathrm{CO}_{2}$ vents in subtropical and tropical habitats (Hall-Spencer et al., 2008; Fabricius et al., 2011; RodolfoMetalpa et al., 2011). However, in these fully marine, naturally acidified systems, seawater remains supersaturated with respect to calcium carbonate when low $p \mathrm{CO}_{2}$ values are encountered (Hall-Spencer et al., 2008; Fabricius et al., 2011). In contrast, very low $\mathrm{CaCO}_{3}$ saturation and frequent undersaturation was found in Kiel Fjord during the entire year, as salinity and alkalinity are lower in this brackish system. In Kiel Fjord, high seawater $p \mathrm{CO}_{2}$ results from aerobic degradation of organic matter in the water masses below the thermocline, an effect which is enhanced by strong eutrophication during the last 50 years (Babenerd, 1991; Melzner et al. 2012). Kiel Fjord thus is an example of a highly productive habitat where eutrophication impacts on the carbonate system are already more severe than 
Table 1 Abiotic seawater conditions and carbonate system parameters (measured: Sal, T, POC, $C_{\mathrm{T}}, \mathrm{pH}$ and calculated: $\mathrm{A}_{\mathrm{T}}$, $p \mathrm{CO}_{2}, \Omega_{\text {calcite }}$ and $\Omega_{\text {aragonite}}$ ) at the field sites (A), final morphometry of individual specimens, plate coverage and $\mathrm{CaCO}_{3}$ production on the settlement panels at the end of the field study (B), values exceeding $100 \%$ coverage result from secondary settlement of Mytilus edulis spat, see panels in Fig. 3, POC and PON concentration and C:N ratio at the field sites. Values represent means $\pm \mathrm{SD}$

\begin{tabular}{|c|c|c|c|c|c|c|c|c|}
\hline A & Carbonate & ystem paramete & & & & & & \\
\hline Site & Salinity & $\begin{array}{l}\text { Temperature } \\
{ }^{\circ} \mathrm{C}\end{array}$ & $\begin{array}{l}C_{\mathrm{T}} \\
\mu \mathrm{mol} \mathrm{kg}{ }^{-1}\end{array}$ & $\begin{array}{l}A_{\mathrm{T}} \\
\mu \mathrm{mol} \mathrm{kg}\end{array}$ & $\begin{array}{l}\mathrm{pH} \\
\text { Total scale }\end{array}$ & $\begin{array}{l}p \mathrm{CO}_{2} \\
\mu \mathrm{atm}\end{array}$ & $\begin{array}{l}\Omega \\
\text { Calcite }\end{array}$ & $\begin{array}{l}\Omega \\
\text { Aragonite }\end{array}$ \\
\hline Inner Fjord & $16.2 \pm 2.0$ & $13.2 \pm 3.0$ & $1996.5 \pm 104.8$ & $2021.1 \pm 95.1$ & $7.76 \pm 0.2$ & $969 \pm 420$ & $1.38 \pm 0.68$ & $0.81 \pm 0.39$ \\
\hline Outer Fjord & $16.0 \pm 1.4$ & $12.5 \pm 2.8$ & $1829.1 \pm 99.8$ & $1945.5 \pm 56.8$ & $7.93 \pm 0.18$ & $599 \pm 283$ & $\begin{array}{l}3.79 \pm 0.65 \\
\end{array}$ & $1.05 \pm 0.38$ \\
\hline B & Single speci & nens & & Settlement plat & & & $y$ & \\
\hline Site & $\begin{array}{l}\text { Shell } \\
\text { length } \mathrm{mm}\end{array}$ & $\begin{array}{l}\text { Shell } \\
\text { mass mg }\end{array}$ & Drymass mg & $\begin{array}{l}\text { Mussel } \\
\text { coverage \% }\end{array}$ & $\begin{array}{l}\text { Barncale } \\
\text { coverage } \%\end{array}$ & $\begin{array}{l}\text { Barnacle } \\
\text { survival \% }\end{array}$ & $\begin{array}{l}\text { Mussel } \mathrm{CaCO}_{3} \\
\text { g plate }^{-1}\end{array}$ & $\begin{array}{l}\text { Barnacle } \\
\mathrm{CaCO}_{3} \\
\text { g plate }^{-1}\end{array}$ \\
\hline $\begin{array}{l}\text { Inner Fjord } \\
\text { Outer Fjord }\end{array}$ & $\begin{array}{r}18.3 \pm 6.8 \\
9.4 \pm 3.4\end{array}$ & $\begin{aligned} 226.6 & \pm 169.4 \\
33.0 & \pm 22.8\end{aligned}$ & $\begin{aligned} 51.1 & \pm 42.2 \\
5.8 & \pm 4.3\end{aligned}$ & $\begin{aligned} 166.7 & \pm 25.8 \\
87.5 & \pm 25.0\end{aligned}$ & $\begin{array}{l}66.7 \pm 44.6 \\
95.0 \pm 10.0\end{array}$ & $\begin{array}{l}24.2 \pm 22.4 \\
62.5 \pm 14.4\end{array}$ & $\begin{array}{l}101.2 \pm 24.3 \\
13.8 \pm 4.9\end{array}$ & $\begin{array}{l}8.0 \pm 2.9 \\
14.2 \pm 4.3\end{array}$ \\
\hline C & & & Nutrition & & & & & \\
\hline Site & & & $\begin{array}{l}\mathrm{POC} \\
\mu \mathrm{g} 1^{-1}\end{array}$ & & $\begin{array}{l}\mathrm{PON} \\
\mu \mathrm{g}^{-1}\end{array}$ & & & $\begin{array}{l}\mathrm{C}: \mathrm{N} \\
\text { Molar ratio }\end{array}$ \\
\hline Inner Fjord & & & $682 \pm 388$ & & $92 \pm 4$ & & & $8.8 \pm 1.8$ \\
\hline Outer Fjord & & & $342 \pm 148$ & & $50 \pm 2$ & & & $8.1 \pm 0.7$ \\
\hline
\end{tabular}
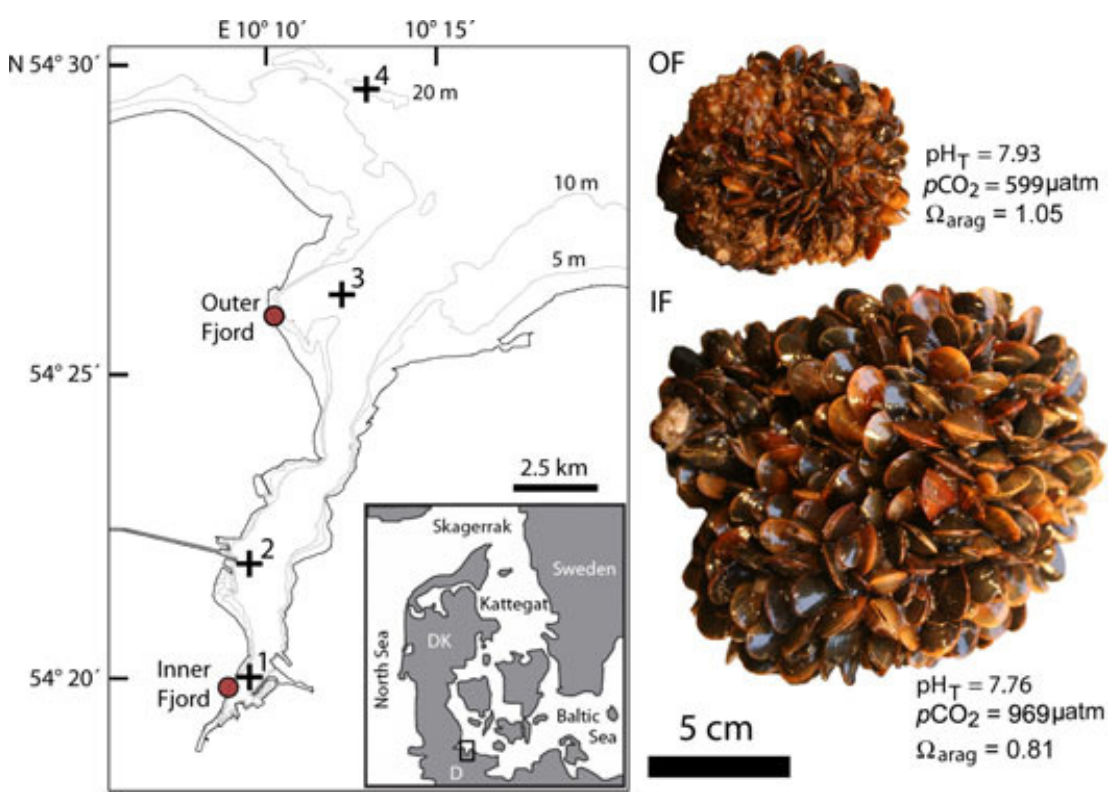

Fig. 3 Map of Kiel Fjord with representative settlement plates from the outer Fjord (OF) and the inner Fjord (IF) and the average carbonate system speciation during the field study, Numbers 1-4 indicate the stations of the carbonate system monitoring program, the brown circles indicate the positions of stations OF and IF, original size of the PVC panels $5 \times 5 \mathrm{~cm}$ (panels are fully overgrown with mussels and barnacles). Pictures are drawn to scale, scale bar $5 \mathrm{~cm}$. 

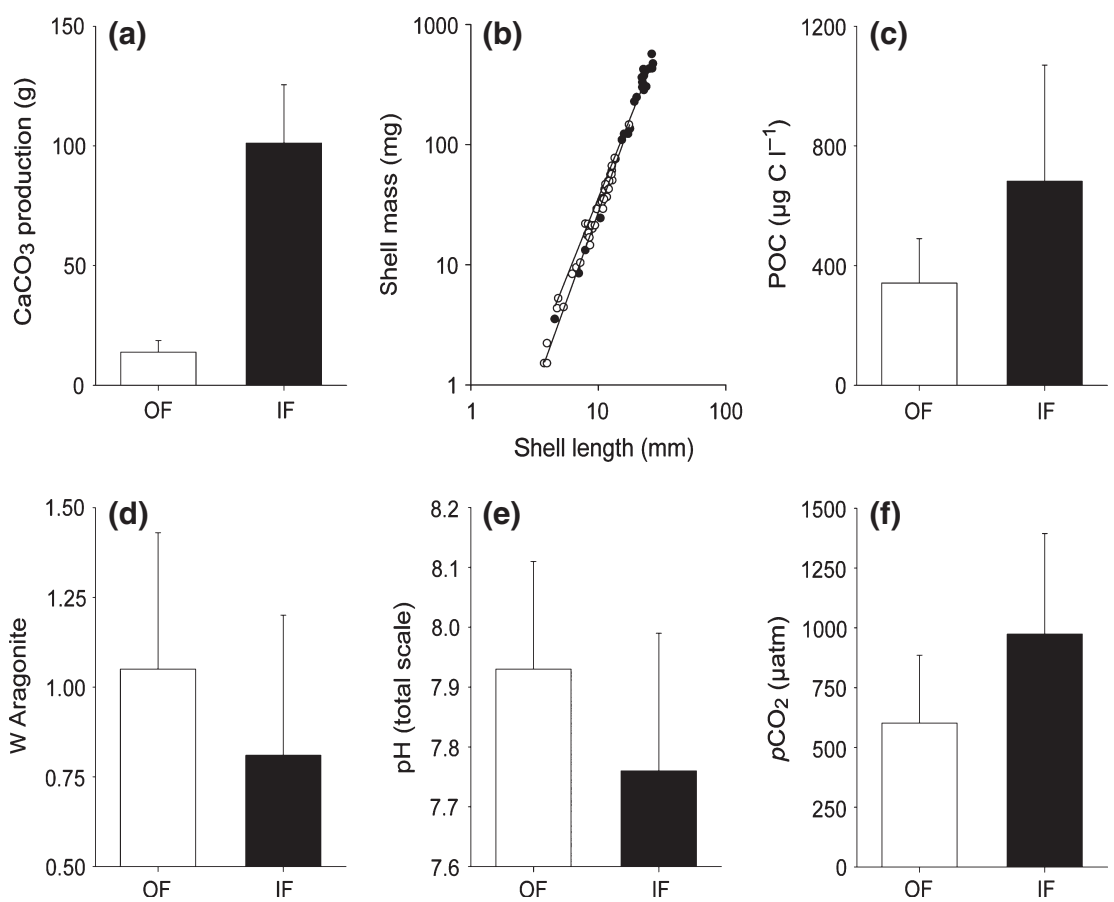

Fig. 4 Results of the field study (outer Fjord: white, inner Fjord: black): Final mean $\mathrm{CaCO}_{3}$ mass of Mytilus edulis per settlement plate (a), Final shell mass and length of individual M. edulis grown at the outer and inner Fjord (b), POC concentrations (c), Mean values for abiotic conditions during the experimental period at both sites (d-f), $\Omega_{\text {aragonite }}(\mathrm{d}), \mathrm{pH}_{\text {total }}(\mathrm{e}), p \mathrm{CO}_{2}$ in $\mu$ atm (f). Bars represent means \pm SD.

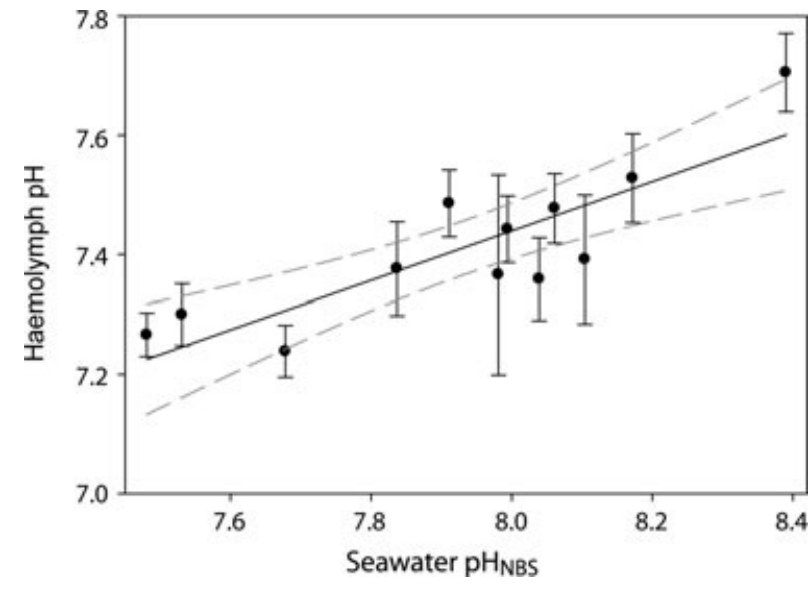

Fig. 5 Relationship of haemolymph $\mathrm{pH}\left(\mathrm{pH}_{\mathrm{HL}}\right)$ of Mytilus edulis and ambient seawater $\mathrm{pH}_{\mathrm{NBS}}\left(\mathrm{pH}_{\mathrm{SW}}\right), \mathrm{pH}_{\mathrm{HL}}=0.413$ $( \pm 0.08) \times \mathrm{pH}_{\mathrm{SW}}+4.14 \quad( \pm 0.64), \quad F_{(1,60)}=26.5 \quad P<0.01$, means $\pm \mathrm{SE}$; each data point represents mean $\pm \mathrm{SD}$ of $n=5$ mussels from one sampling date.

perturbations that are expected through air-sea $\mathrm{CO}_{2}$ uptake in the average surface ocean in the next 100 years (Cao \& Caldeira, 2008; Borges \& Gypens, 2010; Haynert et al., 2012).

The observed fluctuations in seawater $p \mathrm{CO}_{2}$ over the seasonal cycle directly translate into changes in mussel haemolymph $p \mathrm{CO}_{2}$. As M. edulis does not accumu- late bicarbonate in its haemolymph to regulate $\mathrm{pH}$ (Thomsen et al., 2010; Heinemann et al., 2012), extracellular $\mathrm{pH}$ and $\left[\mathrm{CO}_{3}{ }^{2-}\right]$ respond strongly to changes in seawater $p \mathrm{CO}_{2}$. However, as an intertidal species M. edulis is used to cope with strong fluctuations of extracellular $\mathrm{pH}$ - at least on a daily basis (Booth et al., 1984). In contrast, intracellular $\mathrm{pH}$ is strongly regulated and maintained close to control levels under acidification stress (Zange et al., 1990; Michaelidis et al., 2005). To maintain intracellular $\mathrm{pH}$ under changed extracellular acid-base status cellular ion transport needs to be adjusted, which most probably requires additional energy (Deigweiher et al., 2009). This hypothesis is supported by the observation of $\mathrm{CO}_{2}$-induced elevated metabolic rates in several marine invertebrates with limited pHe regulatory capacity - including $M$. edulis (molluscs: Beniash et al., 2010; Thomsen \& Melzner, 2010; echinoderms: Stumpp et al., 2011). Higher maintenance costs for intracellular homeostasis under $\mathrm{CO}_{2}$ stress might be one main cause for the decrease of scope for growth and consequently, reduced calcification rates (Stumpp et al., 2011). Furthermore, the formation of amorphous calcium carbonate precursor (ACC) material for shell formation occurs in intracellular vesicles (Jacob et al., 2008; Weiner \& Addadi, 2011). Excess protons, which are generated intracellularly during calcification, need to be excreted against an increased 
extracellular proton concentration under high environmental $p \mathrm{CO}_{2}$. This might further compromise energy budgets of bivalves under elevated $p \mathrm{CO}_{2}$.

Due to the relative large shell mass and the high organic content of the shell of small mussels $(>10 \%$ of shell mass), calcification is an extremely costly process for the earliest life stages. In adult mussels, matrix proteins only contribute about $5 \%$ to total shell mass (Jörgensen, 1976). Our findings demonstrate that in early juveniles $>60 \%$ of the energy used for body growth is required for shell formation, including about $40 \%$ for its organic content, that is the shell matrix proteins and carbohydrates and the periostracum. Therefore, downregulation of calcification can contribute significantly to energy conservation during unfavourable, low food periods or during exposure to very high ambient $p \mathrm{CO}_{2}$.

However, our laboratory experiment indicates that the negative effects of seawater acidification are marginal compared to those of food supply, with no significant reductions in growth and calcification up to a seawater $p \mathrm{CO}_{2}$ of $2100 \mu \mathrm{atm}$. In agreement with the laboratory results, we observed that moderately elevated $p \mathrm{CO}_{2}$ (ca. $1000 \mu \mathrm{atm}$ ) at field station IF does not lower mussel fitness. Rather, high energy availability enables higher growth and calcification rates and more complete dominance of benthic communities when compared to the lower $p \mathrm{CO}_{2}$ (ca. $600 \mu \mathrm{atm}$ ) station OF.

These findings are in contrast to other field studies along natural $p \mathrm{CO}_{2}$ gradients which observed a strong decrease of the productivity of calcifying metazoans (Hall-Spencer et al., 2008; Fabricius et al., 2011). The high POC concentrations in Kiel Fjord in general and at station IF in particular, enable overcompensation of the adverse carbonate system conditions. Higher organic particle concentrations lead to much higher energy uptake at similar filtration rates, which facilitate higher growth rates and net growth efficiencies. This might partly explain the sevenfold increase in shell mass growth at only twofold elevated POC concentration at 8 station IF (Riisgård \& Randløv, 1981). In other coastal areas with comparable POC availability (e.g. the North Sea), mussels may also compensate negative effects of high $\mathrm{CO}_{2}$ through high energy availability. In contrast, in oligotrophic ocean regions such as the Mediterranean Sea, such compensatory effects might not be possible (Rodolfo-Metalpa et al., 2011). Due to the eutrophication process in the Baltic, the benthic community in Kiel Fjord has been subjected to a rapid change towards high ambient $p \mathrm{CO}_{2}$ within less than 50 years. This has not impacted the dominant position of $M$. edulis in this habitat (Boje, 1965). Thus, M. edulis might be inherently tolerant to high and variable $p \mathrm{CO}_{2}$, or posses an expressed capacity for rapid adaptation to high $p \mathrm{CO}_{2}$ within about 50 generations. Simulated selection of closely related $M$. trossulus larvae under an elevated $p \mathrm{CO}_{2}$ regime indicated the possibility for significant adaptation potential within a similar time period (Sunday et al., 2011). Population specific differences in vulnerability to ocean acidification were already observed in oysters and emphasize the need to compare the responses of Kiel Fjord mussels with other populations from less $\mathrm{CO}_{2}$ enriched areas (Parker et al., 2012).

The results from our field experiment also emphasize the need to consider multi-species responses towards ocean acidification. Barnacles, thought to be more tolerant to acidification than mussels (Pansch et al., 2012a,b), are out-competed at station IF. While $\mathrm{CaCO}_{3}$ production of both species was similar at station OF, mussel $\mathrm{CaCO}_{3}$ production exceeded that of barnacles about 12fold at station IF. This is most probably due to restriction of barnacle food supply by fast growing mussels and very high recruitment intensity. High filtration and $100 \%$ clearance rates of particles $>4 \mu \mathrm{m}$ in M. edulis (Riisgård \& Randløv, 1981), the spatial restriction of the barnacle feeding apparatus in dense mussel assemblages and depletion of planktonic organisms by mussels are probable causes for starvation - induced high mortality $(>75 \%)$ of barnacles at station IF. Therefore, in Kiel Fjord recruitment success of barnacles is more dependent on competition with mussels than on the direct effects of high $p \mathrm{CO}_{2}$ (Pansch et al., 2012a,b). Consequently, results from single species laboratory experiments on $\mathrm{CO}_{2}$ tolerance cannot be extrapolated to the field without considering habitat specific characteristics such as recruitment intensity, competition for space and food availability. In summary, this study demonstrates a high inherent resilience of calcifying benthic communities in an estuarine, eutrophic habitat to elevated seawater $p \mathrm{CO}_{2}$. Food supply, and not $p \mathrm{CO}_{2}$, appears to be the primary factor driving biomass and biogenic $\mathrm{CaCO}_{3}$ production, as well as community structure. Our findings emphasize the need to include additional factors such as habitat energy availability to predict single- and multi-species responses to ocean acidification. Future studies need to address the impact of additional stressors such as temperature increase, as well as the higher sensitivity of the early, planktonic larval stages (Gazeau et al., 2010).

\section{Acknowledgements}

The authors thank Dennis Rossoll, Holger Ossenbrügger, Katja Trübenbach, Luise Töpfer, and Helgi Mempel for supporting carbonate chemistry sampling and Susann Grobe, Tobias Steinhoff, Sebastian Fessler, and Vincent Saderne for help with the measurements. Peter Fritsche and Annegret Stuhr provided nutrient data, Aljosa Zavisic measured POC and Phillipp Schubert contributed the map of Kiel Fjord. Furthermore, we 
acknowledge Ulrike Panknin for maintaining Rhodomonas cultures and Renate Schütt for species determination of the settlement panels. The authors thank three anonymous reviewers for their constructive comments on the earlier versions of this manuscript. This study was funded by the DFG Excellence Cluster ' Future Ocean' and the German 'Biological impacts of ocean acidification (BIOACID)' project 3.1.3, funded by the Federal Ministry of Education and Research (BMBF, FKZ 03F0608A).

Statement of authorship: J. T. and F. M. designed the study, J. T., I. C. and C. P. collected the data, J. T., I. C., A. K., and F. M. analysed the data, J. T. and F. M. wrote the manuscript and all authors contributed substantially to revisions.

\section{References}

Babenerd B (1991) Increasing oxygen deficiency in Kiel Bay (Western Baltic). Marine Research, 33, 121-140.

Beniash E, Ivanina A, Lieb N, Kurochkin I, Sokolova , IM (2010) Elevated level of carbon dioxide affects metabolism and shell formation in oysters Crassostrea virginica. Marine Ecology-Progress Series, 419, 95-108.

Boje R (1965) Die Bedeutung von Nahrungsfaktoren für das Wachstum von Mytilus edulis L. in der Kieler Förde und im Nord-Ostsee Kanal. Kieler Meeresforschung, 21, 81-100.

Booth CE, McDonald DG, Walsh PJ (1984) Acid-base balance in the sea mussel, Mytilus edulis. I. effects of hypoxia and air-exposure on hemolymph acid-base status. Marine Biology Letters, 5, 347-358.

Borges AV, Gypens N (2010) Carbonate chemistry in the coastal zone responds more strongly to eutrophication than to ocean acidification. Limnology \& Oceanography, 55, 346-353.

Brey T, Rumohr H, Ankar S (1988) Energy content of macrobenthic invertebrates: general conversion factors from weight to energy. Journal of Experimental Marine Biology and Ecology, 117, 271-278.

Cai WJ, Hu X, Huang WJ et al. (2011) Acidification of subsurface coastal waters enhanced by eutrophication. Nature Geoscience, 4, 1-5.

Cao L, Caldeira K (2008) Atmospheric $\mathrm{CO}_{2}$ stabilization and ocean acidification. Geophysical Research Letters, 35, L19609.

Deigweiher K, Hirse T, Bock C et al. (2009) Hypercapnia induced shifts in gill energy budgets of Antarctic notothenioids. Journal of Comparative Physiology B, 180, 347-359.

Dickson AG (1990) Standard potential of the reaction $-\mathrm{AgCl}(\mathrm{S})+1 / 2 \mathrm{H}_{2}=\mathrm{Ag}(\mathrm{s})+\mathrm{HCl}$ (Aq) and the standard acidity constant of the ion $\mathrm{HSO}_{4}{ }^{-}$in synthetic sea-water from 273.15 to 318.15-K. Journal of Chemical Thermodynamics, 22, 113-127.

Dickson AG, Afghan JD, Anderson GC (2003) Reference materials for oceanic $\mathrm{CO}_{2}$ analysis: a method for the certification of total alkalinity. Marine Chemistry, 80, 185-197.

Dickson AG, Sabine CL, Christian JR (2007) Guide to Best Practices for Ocean CO2 Mea-

10 surements (Vol. 3, p. 191). PICES Special Publications, ????????.

Fabricius KE, Langdon C, Uthicke S et al. (2011) Losers and winners in coral reefs acclimatized to elevated carbon dioxide concentrations. Nature Climate Change, $\mathbf{1}$ 165-169.

Feely RA, Alin SR, Newton J et al. (2010) The combined effects of ocean acidification, mixing, and respiration on $\mathrm{pH}$ and carbonate saturation in an urbanized estuary. Estuarine. Coastal and Shelf Science, 88, 442-449.

Gazeau F, Gattuso JP, Dawber C et al. (2010) Effect of ocean acidification on the early life stages of the blue mussel Mytilus edulis. Biogeosciences, 7, 2051-2060.

Hall-Spencer JM, Rodolfo-Metalpa R, Martin S et al. (2008) Volcanic carbon dioxide vents show ecosystem effects of ocean acidification. Nature, 454, 96-99.

Haynert K, Schönfeld J, Riebesell U, Polovodova I (2011) Biometry and dissolution features of the benthic foraminifer Ammonia aomoriensis at high $p \mathrm{CO}_{2}$. Marine Ecology-Progress Series, 432, 53-67.

Haynert K, Schönfeld J, Polovodova-Asteman I, Thomsen J (2012) The benthic foraminiferal community in a naturally $\mathrm{CO}_{2}$-rich coastal habitat of the southwestern Baltic Sea. Biogeosciences, 9, 4421-4440.

Heinemann A, Fietzke J, Melzner F, Böhm F, Thomsen J, Garbe-Schönberg D, Eisenhauer A (2012) Conditions if Mytilus edulis extracellular body fluids and shell composition in a $\mathrm{pH}$-treatment experiment: acid-base status, trace elements and $\delta^{11} \mathrm{~B}$ Geochemistry Geophysics Geosystems, 132, Q01005.

HELCOM (2009) Eutrophication in the Baltic Sea - an integrated thematic assessment of the effects of nutrient enrichment and eutrophication in the Baltic Sea region. Baltic Sea Environmental Porceedings, 115B, ???-???
Hofmann GE, Smith JE, Johnson KS et al. (2011) High-frequency dynamics of ocean pH: a multi-ecosystem comparison. PLoS ONE, 6, e28983.

Jacob DE, Soldati AL, Wirth R et al. (2008) Nanostructure, composition and mechanisms of bivalve shell growth. Geochimica et Cosmochimica Acta, 72, 5401-5415.

Jörgensen C (1976) Growth efficiencies and factors controlling size in some mytilid bivalves, especially Mytilus edulis L.: review and interpretation. Ophelia, 15, 175 192.

Kurihara H, Asai T, Kato S, Ishimatsu A (2008) Effects of elevated $p \mathrm{CO}_{2}$ on early development in the mussel Mytilus galloprovincialis. Aquatic Biology, 4, 225-233.

Lewis E, Wallace DWR (1998) Program Developed for $\mathrm{CO}_{2}$ System Calculations. Oak Ridge National Laboratory ORNL/CDIAC-105, Oak Ridge.

Lischka S, Büdenbender J, Boxhammer T, Riebesell U (2011) Impact of ocean acidification and elevated temperatures on early juveniles of the polar shelled pteropod Limacina helicina: mortality, shell degradation, and shell growth. Biogeoscience, 8, 919-932.

Michaelidis B, Ouzounis C, Paleras A, Pörtner HO (2005) Effects of long-term moderate hypercapnia on acid-base balance and growth rate in marine mussels Mytilus galloprovincialis. Marine Ecology-Progress Series, 293, 109-118.

Palmer AR (1992) Calcification in marine mollusks - how costly is it. Proceedings of the National Academy of Science USA, 89, 1379-1382.

Pansch C, Nasrolahi A, Appelhans YS, Wahl M (2012a) Impacts of ocean warming and acidification on the larval development of the barnacle Amphibalanus improvisus. Journal of Experimental Marine Biology and Ecology, 420-421, 48-55.

Pansch C, Nasrolahi A, Appelhans YS, Wahl M (2012b) Tolerance of juvenile barnacles (Amphibalanus improvisus) to warming and elevated $p \mathrm{CO}_{2}$. Marine Biology, ??? ???-???, in press. doi: 10.1007/s00227-012-2069-4

Parker LM, Ross PL, O'Connor WA, Borysko L, Raftos DA, Pörtner HO (2012) Adult exposure influences offspring response to ocean acidification. Global Change Biology, 18, 82-92.

Ries JB, Cohen AL, McCorkle DM (2009) Marine calcifiers exhibit mixed responses to $\mathrm{CO}_{2}$-induced ocean acidification. Geology, 37, 1131-1134.

Riisgård HU, Randløv A (1981) Energy budgets, growth and filtration rates in Mytilus edulis at different algal concentrations. Marine Biology, 61, 227-234

Rodolfo-Metalpa R, Houlbréque F, Tambutté É et al. (2011) Coral and mollusc resistance to ocean acidification adversely affected by warming. Nature Climate Change, 1, 308-312.

Roy R, Roy L, Vogel Ket al. (1993) The dissociation constants of carbonic acid in seawater at salinities 5 to 45 and temperatures 0 to $45^{\circ} \mathrm{C}$. Marine Chemistry, 44, 249267.

Salonen K, Sarvala J, Hakala I, Viljanen M (1976) The relation of energy and organic carbon in aquatic invertebrates. Limnology \& Oceanography, 21, 724-730.

Smetacek V (1985) The annual cycle of Kiel Bight plankton: a long-term analysis. Estuaries, 8, 145-157.

Stuckas H, Stoof K, Quesada H, Tiedemann R (2009) Evolutionary implications of discordant clines across the Baltic Mytilus edulis hybrid zone (Mytilus edulis and Mytilus trossulus). Heredity, 103, 1-11.

Stumpp M, Wren J, Melzner F, Thorndyke MC, Dupont S (2011) $\mathrm{CO}_{2}$ induced seawater acidification impacts sea urchin larval development I: Elevated metabolic rates decrease scope for growth and induce developmental delay. Comparative Biochemical Physiology A, 160, 331-340.

Sunday JM, Crim RN, Harley CDG, Hart MW (2011) Quantifying rates of evolutionary adaptation in response to ocean acidification. PLoS ONE, 6, e22881.

Talmage SC, Gobler CJ (2010) Effects of past, present, and future ocean carbon dioxide concentrations on the growth and survival of larval shellfish. Proceedings of the National Academy of Science USA, 107, 17246-17251

Thomsen J, Melzner F (2010) Moderate seawater acidification does not elicit longterm metabolic depression in the blue mussel Mytilus edulis. Marine Biology, 157, 2667-2676.

Thomsen J, Gutowska MA, Saphörster J et al. (2010) Calcifying invertebrates succeed in a naturally $\mathrm{CO}_{2}$ enriched coastal habitat but are threatened by high levels of future acidification. Biogeosciences, 7, 3879-3891.

Weiner S, Addadi L (2011) Crystallization pathways in biomineralization. Annual Review of Materials Research, 41, 21-40.

Weiss RF (1974) Carbon dioxide in water and seawater: the solubility of a non-ideal gas. Marine Chemistry, 2, 203-215.

Wootton JT, Pfister CA, Forester JD (2008) Dynamic patterns and ecological impacts of declining ocean $\mathrm{pH}$ in a high-resolution multi-year dataset. Proceedings of the National Academy of Science USA, 105, 18848-18853.

Zange J, Grieshaber MK, Jans AW (1990) The regulation of intracellular pH estimated by ${ }^{31} \mathrm{P}$ - NMR spectroscopy in the anterior byssus retractor muscle of Mytilus edulis L. Journal of Experimental Biology, 150, 95-109. 